This is the author's final, peer-reviewed manuscript as accepted for publication. The publisher-formatted version may be available through the publisher's web site or your institution's library.

\title{
Purification of a recombinant baculovirus of Autographa californica M nucleopolyhedrovirus by ion exchange membrane chromatography
}

Tanja A. Grein, Ronald Michalsky, Maria Vega López, Peter Czermak

\section{How to cite this manuscript}

If you make reference to this version of the manuscript, use the following information:

Grein, T. A., Michalsky, R., López, M. V., \& Czermak, P. (2012). Purification of a recombinant baculovirus of Autographa californica $M$ nucleopolyhedrovirus by ion exchange membrane chromatography. Retrieved from http://krex.ksu.edu

\section{Published Version Information}

Citation: Grein, T. A., Michalsky, R., López, M. V., \& Czermak, P. (2012). Purification of a recombinant baculovirus of Autographa californica $\mathrm{M}$ nucleopolyhedrovirus by ion exchange membrane chromatography. Journal of Virological Methods, 183(2), 117-124.

Copyright: @ 2012 Elsevier B.V.

Digital Object Identifier (DOI): doi:10.1016/j.jviromet.2012.03.031

Publisher's Link: http://www.sciencedirect.com/science/article/pii/S0166093412001103

This item was retrieved from the K-State Research Exchange (K-REx), the institutional repository of Kansas State University. K-REx is available at http://krex.ksu.edu 


\title{
Purification of a recombinant baculovirus of Autographa californica M nucleopolyhedrovirus by ion exchange membrane chromatography
}

\author{
Tanja A. Grein ${ }^{1}$, Ronald Michalsky ${ }^{2}$, Maria. Vega López ${ }^{2, \#}$, Peter Czermak ${ }^{1,2, *}$ \\ ${ }^{1}$ University of Applied Sciences Mittelhessen, Institute of Bioprocess Engineering and \\ Pharmaceutical Technology, Wiesenstrasse 14, 35390 Giessen, Germany \\ ${ }^{2}$ Kansas State University, Department of Chemical Engineering, Manhattan, Kansas, 66506, \\ U.S.A.
}

\begin{abstract}
Significant progress in the application of viral vectors for gene delivery into mammalian cells and the use of viruses as biopesticides requires downstream processing that can satisfy application-specific demands on performance. In the present work the stability and ion exchange membrane chromatography of a recombinant of Autographa californica M nucleopolyhedrovirus is studied. To adjust the degree of purification the effect of ionic conductivity or $\mathrm{pH}$ on the viral infectivity was assessed $(0.77-78.00 \mathrm{mS} / \mathrm{cm}, \mathrm{pH} 3-8)$. Infectivity decreased rapidly by several orders of magnitude at below $5 \mathrm{mS} / \mathrm{cm}$ (i.e., $0.49 \mathrm{MPa}$ osmotic pressure change) or at below $\mathrm{pH}$ 5.5 (rationalized with particle aggregation). The virus was concentrated and purified via adsorption $\left(0.2-1.1 \times 10^{16} \mathrm{pfu} / \mathrm{m}^{3}\right.$ chromatographic bed volume, $0.6-1.1 \times 10^{12} \mathrm{pfu} / \mathrm{m}^{2}$ membrane area facing the incident fluid flow) and elution at $\mathrm{pH} 6.1$ and $6.35 \mathrm{mS} / \mathrm{cm}$ from three strong anion exchange membranes. Virus recovery and concentration in accord with the volume reduction were obtained using a polyether sulfone-based membrane with quaternary ammonium ligands. The level of host cell protein (down to below the detection limit) and suspended DNA (below 93 pg DNA per $10^{6} \mathrm{pfu}$ ) are reported for each membrane employed, for the purpose of comparability, under equal adsorption or elution conditions respectively.
\end{abstract}

Keywords: Gene therapy; Pesticide; Baculovirus; Ion exchange membrane chromatography; Conductivity; $\mathrm{pH}$ 
* Corresponding author - postal address: University of Applied Sciences Mittelhessen, Wiesenstrasse 14, 35390 Giessen, Germany; phone: +49 641309 2551; fax: +49 641309 2553; e-mail: Peter.Czermak@kmub.THM.de

* Current address: Universidad de Oviedo, Departamento de Ingeniería Química y Tecnología del Medio Ambiente, 33006 Oviedo, Spain 


\section{Introduction}

Insect viruses are central components of current manufacturing processes producing recombinant proteins such as enzymes (Vicente et al., 2010; Vicente et al., 2009) and human or animal vaccines (Justice et al., 2011) at industrial scale (virus cultures in the order of several $\mathrm{m}^{3} /$ day, Boehringer Ingelheim Vetmedica). For decades large scale applications of biopesticides (in the order of $10^{4} \mathrm{~km}^{2} /$ year (Moscardi, 1999)) have made use of insect viruses targeting specifically their hosts (Mishra, 1998; Moscardi, 1999; Oliveira et al., 2006). This ecologically benign response to the increasing demand for agricultural production requires biopesticides that can compete economically with conventional chemical pesticides. Thus, a major criterion for assessing the value of a biopesticide is its price per infective unit. This is determined significantly by the complexity and durability of the downstream manufacturing process of the viral pesticide. On the other hand, highly purified insect viruses are employed as viral vectors in the clinical development of vaccines, e.g., for lymphoma patients (Betting et al., 2009). Similarly, academic research studying, e.g., the underpinnings of viral pathogenesis (Goley et al., 2006) utilize ultrapure viral dispersions with minimum DNA and host cell protein levels.

Baculoviruses have been applied globally for control of Lepidoptera pests, e.g., in soybean and cotton crops (Moscardi, 1999) and have been studied as a vector for gene therapy (Liang et al., 2003; Long et al., 2006). In 2009 the FDA approved Cervarix (GlaxoSmithKlineBiologicals), a vaccine against two main types of cancer-causing human papillomavirus produced with the Baculovirus Expression System (Betting et al., 2009). A baculovirus used commonly for biopesticide production and for expression of recombinant proteins, Autographa californica $\mathrm{M}$ nucleopolyhedrovirus (AcMNPV), is an enveloped dsDNA virus infectious for lepidopteran insects. AcMNPV exists in two forms, budded virus and occluded virus. The rod- 
shaped budded virus (approximately 15 to $40 \mathrm{~nm}$ x 200 to $300 \mathrm{~nm}$ in size) is assembled in the first phase of infection. This virus form contains a single nucleocapsid surrounded by an envelope obtained from the host cell plasma membrane when the virus is released from infected cells into the surrounding medium (Ihalainen et al., 2009; O’Reilly, 1994; Rohrmann, 1992).

Various methods for virus concentration and purification exist (for a thorough review of state of the art bioprocessing of baculoviruses see (Aucoin et al., 2010)). At small scale viruses can be concentrated and purified via sucrose density centrifugation. This results in low production rates and low yields but high purity virus dispersions (Aboud et al., 1982; Aranha, 2001). At large scale, virus membrane filtration represents a beneficial trade-off. Membranebased filtration can process potentially large volumes, yielding high virus concentrations and recovering infectivity and membrane performance on one hand. The purity of the viral product on the other hand can be tuned if the membrane is equipped with an electric charge carrier.

Given the broad range of applications for AcMPNV in industry and research and development, membrane-based filtration of AcMPNV has received great interest in the past. This includes the use of ultrafiltration membranes, ion exchange membranes and resin-based chromatography (Barsoum, 1999; Michalsky et al., 2009; Transfiguracion et al., 2011; Wu et al., 2007). However, the purification of AcMPNV is developed poorly (Vicente et al., 2010; Vicente et al., 2009) and materials and processes for the efficient downstream processing of baculoviruses for clinical applications is sought (Vicente et al., 2010; Vicente et al., 2009).

In general, adsorptive membranes have been studied as an alternative to conventional resin-based chromatography columns (Ghosh, 2002; Klein, 2000). Adsorptive membranes benefit from shorter diffusion times (i.e., mass-transfer of the molecule of interest to and from the active sites on the membrane or resin) relative to those obtained with resin-based chromatography (Barsoum, 1999). This may reduce significantly the size and cost of unit 
operations for the industrial-scale downstream processing of virus dispersions. Ion exchange membrane chromatography (IEMC) is based on adsorptive membranes that employ the electric interaction between charged components of a liquid phase (e.g., viruses) and ionic groups immobilized on the solid membrane matrix. This is a conceivably simple and efficient method for virus concentration and purification. In contrast to sucrose density centrifugation, aggregation of viral particles and loss of viral activity due to hydrodynamic shear stress are decreased by the use of ion exchange chromatography (Barsoum, 1999). Compared to conventional resin-based chromatography, IEMC shows relatively high capacities for biological macromolecules and a decreased sensitivity to flow rates affecting product yield and purity (Yang et al., 2002).

Previous studies have addressed the physical stability (Jorio et al., 2006a; Oliveira et al., 2006) of a recombinant of AcMNPV (Michalsky et al., 2008) and have assessed simple virus concentration via tangential ultrafiltration with commercial polysulfone membranes (Michalsky et al., 2009; Wu et al., 2007). Based on this work, a comparison of three different adsorptive membranes for concentration and purification of a recombinant of AcMNPV is provided here. To control product purity, yield and recovery of infectivity, the feasible range for adjusting the ionic conductivity or the $\mathrm{pH}$ during IEMC-based filtration of AcMNPV was determined. Thereafter, virus filtration experiments were conducted under conditions (non-isoelectric elution at increased ionic conductivity) aiming for a maximum viral product yield rather than product purity. Three strong anion exchange membranes (cellulose or polyether sulfone membranes with functional quaternary ammonium groups or polyethylene membranes coated with poly(allylamine)) were utilized for separation of AcMNPV from crude cell culture media. Recovery and maximum concentration of infectivity are reported along with diminished host cell protein and suspended DNA levels. 


\section{Materials and Methods}

\subsection{Cells and virus}

Cells of the IPLB-SF21-AE (SF-21) cell line adapted to Sf-900 II Serum Free Medium (SFMII) (Invitrogen) were grown in SFMII (pH 6.1, 0.36 osmol $/ \mathrm{kg}$ ) (Invitrogen) at $27^{\circ} \mathrm{C}$ using Erlenmeyer flasks rotated at $100 \mathrm{rpm}(\mathrm{H}+\mathrm{P}$ Labortechnik). Cell cultures were passaged twice a week as described previously (O’Reilly et al., 1994).

A recombinant of AcMNPV, vHSGFP containing the enhanced green fluorescent protein gene (egfp) controlled by the Drosophila heat shock protein 70 (hsp70) promoter has been described elsewhere (Clarke and Clem, 2002) and was used here for virus cultivations. The virus was a gift from Professor A. Lorena Passarelli, Division of Biology, Kansas State University, Manhattan, KS, USA. To obtain a virus stock SF-21 cultures were infected with vHSGFP at a multiplicity of infection (MOI) of 0.1 plaque forming units per cell (pfu/cell). The budded virus in the supernatant was harvested 5 days post infection by centrifugation $(1000 \mathrm{x} \mathrm{g}, 10 \mathrm{~min}$, at room temperature), and stored in the dark at $4{ }^{\circ} \mathrm{C}$ in polypropylene bottles (Jarvis et al., 1994; Jorio et al., 2006a; O’Reilly, 1994).

\subsection{Virus infectivity}

$\mathrm{TCID}_{50}$ endpoint dilution was used to determine virus infectivity in $\mathrm{pfu} / \mathrm{ml}$ (with an error of ca. 0.5 orders of magnitude (O’Reilly, 1994; Roldão et al., 2009)) as described previously. Briefly, SF-21 cells $\left(10^{5}\right.$ cells $\left./ \mathrm{ml}\right)$ aliquoted on $96-$ well cell culture dishes (Greiner Bio One) were infected with virus dilutions ranging from $10^{-1}$ to $10^{-10} \mathrm{pfu} / \mathrm{ml}$. Infectious virus was determined by counting wells containing infected cells identified by green fluorescence at 5 days post infection (Wilovert AFL 20 microscope, Sybrgreen fluorescence emission filter, Hund $\mathrm{GmbH})$. 


\subsection{Protein analysis}

Protein concentrations were determined using the Bradford assay ( $80 \mu \mathrm{l}$ sample mixed with $20 \mu \mathrm{l}$ Bradford reagent containing $0.5 \mathrm{mg} / \mathrm{ml}$ coomassie blue, $25 \mathrm{vol} \%$ ethanol, $42.5 \mathrm{vol} \%$ orthophosphoric acid and 32.5 vol\% $\mathrm{H}_{2} \mathrm{O}$ ). Samples were incubated in absence of light for 15 min on 96-well cell culture dishes (Greiner Bio One). A linear calibration $\left(\mathrm{R}^{2}>0.988\right)$ using 0.1 to $1.0 \mathrm{mg} / \mathrm{ml}$ bovine serum albumin standards was used to estimate protein concentrations of samples detected for absorbance at $595 \mathrm{~nm}$ (Synergy HT Multimode-Reader, Biotek).

Sodium dodecyl sulfate polyacrylamide gel electrophoresis (SDS-PAGE) using the TV50 Vertical Electrophoresis Chamber (Fisherbrand) was utilized to validate the degree of virus purification. Samples taken from the washing (Fraction 4 and 9) and elution step (Fraction 11 and 14) were diluted 4:1 in NuPAGE® LDS Sample Buffer (4X), incubated for 10 min at $95^{\circ} \mathrm{C}$, and thereafter loaded (together with 1:4 dilutions of virus dispersion before purification) into a NuPAGE® $4-12 \%$ Bis Tris Gel (Invitrogen). After separation (200 V, ice bath) the gel was stained using the Pierce ${ }^{\circledR}$ Silver Stain Kit (Thermo Scientific).

\subsection{DNA quantification}

The suspended DNA level in all viral dispersions before and after filtration experiments was determined with Sybr Green I $(0.5 \mathrm{mg} / \mathrm{ml})$ at $488 \mathrm{~nm}$ excitation wavelength and $528 \mathrm{~nm}$ emission wavelength (Sigma-Aldrich). The assay was calibrated in a linear range $\left(R^{2}>0.999\right)$ from $1.0 \times 10^{-11}$ to $1.3 \times 10^{-3} \mathrm{~g} / \mathrm{ml}$ deoxyribonucleic acid (calf thymus standard). Samples were incubated in absence of light for 5 min on 96-well cell culture dishes (Greiner Bio One). Fluorescence was measured with the Synergy HT Multimode-Reader (Biotek). 


\subsection{Virus stability}

To test for virus inactivation due to elution of the virus from the membrane, the effect of $\mathrm{pH}$ on infectivity in harvested virus dispersions was assessed. The $\mathrm{pH}$ (SG8-SevenGo pro $^{\mathrm{TM}}$ $\mathrm{pH} / \mathrm{Ion}$; Mettler Toledo) of harvested virus dispersion (ca. $\mathrm{pH}$ 6) was adjusted in the range of $\mathrm{pH}$ 3.0-8.0 using $1 \mathrm{~mol} / 1 \mathrm{HCl}$ or $1 \mathrm{~mol} / \mathrm{l} \mathrm{NaOH}$ respectively. To correlate virus infectivity and virus particle aggregation, virus infectivity and absorption at $595 \mathrm{~nm}$ (multifunction plate reader, Synergy HT Multimode-Reader, Biotek) was detected in 40 aliquots $(1 \mathrm{ml})$ taken from the virus dispersion with step-wise adjusted $\mathrm{pH}$ values.

To study the effect of a sudden change of ionic conductivity $(\kappa)$ on virus infectivity $\kappa$ (measured with SG8-SevenGo pro $^{\mathrm{TM}} \mathrm{pH} / \mathrm{Ion}$; Mettler Toledo) of harvested virus dispersion $(8.1 \pm 0.4 \mathrm{mS} / \mathrm{cm}$, i.e., ionic strength of $0.360 \pm 0.007 \mathrm{osmol} / \mathrm{kg})$ was adjusted in the range of 0.77 to $78.00 \mathrm{mS} / \mathrm{cm}$ (i.e., $0.16 \pm 0.02$ to $0.77 \pm 0.01 \mathrm{osmol} / \mathrm{kg}$ ) with $\mathrm{NaCl}$ or deionised water respectively. Virus infectivity was detected in 13 samples $(10 \mathrm{ml})$ at 0 and $24 \mathrm{~h}$ (stored in the dark at $4{ }^{\circ} \mathrm{C}$ ). Osmolality was measured utilizing the Osmometer Typ 6 (Löser Messtechnik).

\subsection{Ion exchange membrane chromatography}

To assess the applicability of strong anion exchange membranes for concentration and purification of AcMNPV's budded virus cellulose-based $\left(4.6 \times 10^{-7} \mathrm{~m}^{3}\right.$ chromatographic bed volume, Sartobind Q, Sartorius, SQ) and polyether sulfone-based adsorptive membranes (5.4 x $10^{-7} \mathrm{~m}^{3}$ chromatographic bed volume, Mustang Q, Pall, MQ) with quaternary ammonium functional groups (both $5.48 \times 10^{-4} \mathrm{~m}^{2}$ fluid inflow cross-section area per membrane layer, 3 membrane layers used) were tested (membrane holder from Schüller \& Schnell) (Fig. 1). Additionally, performance of an ultra-high weight polyethylene-based adsorptive membrane coated with poly(allylamine) $\left(8.0 \times 10^{-8} \mathrm{~m}^{3}\right.$ bed volume, $1.00 \times 10^{-4} \mathrm{~m}^{2}$ fluid inflow cross-section area per membrane layer, 8 membrane layers used, ChromaSrob, Millipore, CS) was studied. 
Membranes were equilibrated for $10 \mathrm{~min}$ with $10 \mathrm{ml} 20 \mathrm{mmol} / 1$ Tris buffer $(\mathrm{pH} \mathrm{6.5)}$ and loaded with $3 \mathrm{ml}$ virus dispersion $\left((3.4 \pm 1.2) \times 10^{8} \mathrm{pfu} / \mathrm{ml}\right)$ (Pharmacia LKB peristaltic pump P1, Thermo Scientific; Pharmamed ${ }^{\circledR}$ BPT silicon hose, Saint Gobain Performance Plastic Cooperation). After washing with $6 \mathrm{ml} 20 \mathrm{mmol} / 1$ Tris buffer virus was eluted with $3 \mathrm{ml}$ $0.15 \mathrm{~mol} / 1 \mathrm{NaCl}$ followed by $3 \mathrm{ml} 0.5 \mathrm{~mol} / 1 \mathrm{NaCl}$. All liquid flow rates were $1 \mathrm{ml} / \mathrm{min}$ at approximately $25^{\circ} \mathrm{C}$. The eluate was fractionated into $1 \mathrm{ml}$ aliquots for analysis.

\subsection{Chemicals}

HCL (aqueous solution, $37 \mathrm{wt} \%$ ), $\mathrm{NaOH}$ (pellets, $\geq 98.0 \mathrm{wt} \%$ ) and $\mathrm{NaCl}$ (powder, $\geq 99.5$ wt $\%$ ) were from Merck. Coomassie blue and orthophosphoric acid ( $85 \mathrm{wt} \%)$, were purchased from AppliChem. Tris buffer, bovine serum albumin (cell culture grade) and ethanol (98 wt\%) were from Sigma Aldrich. Water was deionised using the Milli-Q Academic water purification system (Millipore).

\section{Results}

\subsection{The effect of $\mathrm{pH}$ and ionic conductivity on viral infectivity}

Infectivity decreased 3 orders of magnitude from $(7.9 \pm 5.7) \times 10^{6} \mathrm{pfu} / \mathrm{ml}$ at $\mathrm{pH} 6.0 \pm 0.3$ to $(6.6 \pm 0.7) \times 10^{3} \mathrm{pfu} / \mathrm{ml}$ at $\mathrm{pH} 4.9 \pm 0.3$. Decrease of viral infectivity was accompanied by an increase of light absorption (Fig. 2). The virus titer was under the detection limit when the $\mathrm{pH}$ was further decreased to $\mathrm{pH}$ 3. In the same $\mathrm{pH}$ range light absorbance reached a local maximum at ca. $\mathrm{pH} 4.1 \pm 0.3$. Particle sedimentation was not observed. Increasing the $\mathrm{pH}$ from 6 to 8 did not change the virus titer significantly but increased light absorbance at $\mathrm{pH} 8$.

Virus infectivity decreased approximately 3 orders of magnitude from $(2.5 \pm 1.2) \times 10^{6}$ $\mathrm{pfu} / \mathrm{ml}$ at $8.1 \pm 0.4 \mathrm{mS} / \mathrm{cm}$ to $(5.9 \pm 2.9) \times 10^{3} \mathrm{pfu} / \mathrm{ml}$ at $1.20 \pm 0.02 \mathrm{mS} / \mathrm{cm}$ (Fig. 3$)$. The effect was instantaneous and storage for $24 \mathrm{~h}$ at $4{ }^{\circ} \mathrm{C}$ did not alter significantly infectivity. Simple 
dilution of virus dispersions (1:20) when decreasing $\kappa$ to $0.77 \pm 0.01 \mathrm{mS} / \mathrm{cm}$ yielded $(1.9 \pm 1.0) \times 10^{4} \mathrm{pfu} / \mathrm{ml}$ and thus does not explain entirely the decreased infectivity observed. Infectivity was below detection limits at $\kappa<0.77 \mathrm{mS} / \mathrm{cm}$ (data not shown). In the range of 10-20 $\mathrm{mS} / \mathrm{cm}$ the change in infectivity did not exceed the detection uncertainty. Opposing results obtained at low $\kappa$, infectivity of virus dispersions at $>15 \mathrm{mS} / \mathrm{cm}$ decreased instantaneously by ca. 1 order of magnitude and thereafter slowly by a total of ca. 3 orders of magnitude after $24 \mathrm{~h}$.

\subsection{Virus concentration via ion exchange membrane chromatography}

Dispersions of a recombinant of AcMNPV (3 ml) were loaded (fraction 1 to 3 ) onto strong anion exchange membranes (Fig. 4). The membranes were washed subsequently with $6 \mathrm{ml}$ buffer (fraction 4 to 9), flushed with $3 \mathrm{ml}$ elution buffer at $0.15 \mathrm{~mol} / 1 \mathrm{NaCl}$ (fraction 10 to 12) and $3 \mathrm{ml} 0.5 \mathrm{~mol} / 1 \mathrm{NaCl}$ (fraction 13 to 15$)$ (Fig. 1). Of the $(3.4 \pm 1.7) \times 10^{8} \mathrm{pfu} / \mathrm{ml}$ loaded ca. $98.4 \%, 99.0 \%$, or $89.4 \%$ were adsorbed by the MQ, SQ, or CS membranes after washing respectively. Washing the membranes eluted minor amounts of infectious virus (1.0\% (MQ), $0.7 \%(\mathrm{SQ})$, or $5.8 \%(\mathrm{CS}))$ perhaps due to reduced particle-membrane interaction when reaching the binding capacity of the membrane material. Apparent binding capacities (defined as infectious virus in pfu absorbed by the chromatographic bed volume in $\mathrm{m}^{3}$ after flushing with buffer) were determined based on a balance of infectious particles (Table 1).

Flushing the membranes with $0.15 \mathrm{~mol} / 1 \mathrm{NaCl}$ yielded only minor amounts of virus in the eluate (Fig. 4). Elution with $0.5 \mathrm{~mol} / 1 \mathrm{NaCl}$ yielded viral titer of $(1.1 \pm 0.5) \times 10^{9} \mathrm{pfu} / \mathrm{ml}(\mathrm{MQ}$, Fig. 4A), $(4.8 \pm 1.2) \times 10^{8} \mathrm{pfu} / \mathrm{ml}\left(\mathrm{SQ}\right.$, Fig. 4B), or $(1.4 \pm 0.9) \times 10^{4} \mathrm{pfu} / \mathrm{ml}(\mathrm{CS}$, Fig. $4 \mathrm{C})$, that is concentration of infectious virus by a factor of ca. 1.4 (SQ) to 3.3 (MQ). Regarding the CS membrane, $>99.99 \%$ of the virus adsorbed was bound irreversibly (assuming that the fraction of virus remaining on the membrane after elution closes the balance of infectious particles). 


\subsection{Virus purification}

From approximately $0.13 \pm 0.01 \mathrm{mg}$ protein suspended per $\mathrm{ml}$ harvested virus dispersion ca. $30.3 \mathrm{wt} \%, 64.6 \mathrm{wt} \%$, or $70.6 \mathrm{wt} \%$ were adsorbed by the MQ, SQ, or CS membranes after washing with Tris buffer respectively (Fig. 4). This relates to binding of host cell protein (HCP) in $\mathrm{kg}$ HCP per $\mathrm{m}^{3}$ chromatographic bed volume of $(0.24 \pm 0.03) \mathrm{kg} / \mathrm{m}^{3}$ (MQ), $(0.50 \pm 0.03)$ $\mathrm{kg} / \mathrm{m}^{3}(\mathrm{SQ})$, and $(3.44 \pm 0.01) \mathrm{kg} / \mathrm{m}^{3}(\mathrm{CS})$. After elution of the virus from the membrane material HCP in fraction 14 decreased by a factor of $7.62 \times 10^{-4} \mathrm{~g} / \mathrm{g}$ (SQ), or $5.97 \times 10^{-2} \mathrm{~g} / \mathrm{g}$ (CS). HCP concentrations were below the detection limit when using the MQ membrane material.

SDS-PAGE analysis shows that the first fraction of the washing step (fraction 4) using any of the tested membrane materials contains proteins with a molar mass below $30 \mathrm{kDa}$ (Fig.5). Protein concentrations at the final stage of the washing step (fraction 9) and the first elution step (fraction 11) are below the detection limited. The analysis of the second elution step (fraction 14) yields protein bands correlating with the virus-specific GP64 surface protein (64 kDa) when employing the MQ and SQ membrane. Fraction 14 taken from the filtration using the CS membrane materials does not exhibit a virus-specific band.

IEMC decreased the levels of DNA that is suspended freely in the virus dispersions (compare 2.6) from $674 \pm 35 \mathrm{ng} / \mathrm{ml}$ (harvested virus dispersion) to ca. (95 \pm 5$) \mathrm{ng} / \mathrm{ml}$ (MQ), (154 $\pm 8) \mathrm{ng} / \mathrm{ml}(\mathrm{SQ})$ or $(6.2 \pm 0.3) \mathrm{ng} / \mathrm{ml}(\mathrm{CS})$ detected at maximum in the eluted fractions respectively (Fig. 6). This relates to a reduction of approximately $85.9 \mathrm{wt} \%$ (MQ), $77.1 \mathrm{wt} \%$ (SQ), or $99.1 \mathrm{wt} \%$ (CS) maximum DNA concentration in the eluate relative to the DNA level detected in harvested virus dispersion respectively. 


\section{Discussion}

\subsection{Parameters to control the downstream processing}

The $\mathrm{pH}$ and/or the ionic conductivity in the eluate may be utilized to control the product purity, yield and recovery of infectivity of a virus dispersion during IEMC. In principle, infectivity of viral dispersions was maintained essentially constant in the range of $\mathrm{pH} 6-8$ and 8-

$15 \mathrm{mS} / \mathrm{cm}$ (Fig. 2 and 3). Based on the stability testing (see section 3.1) the ionic conductivity may be adjusted for a short time in the range of $15-80 \mathrm{mS} / \mathrm{cm}$ if the primary goal of the downstream process is high purity rather than high recovered infectivity (see 4.1.2 and 5.).

\subsubsection{Net-surface charge of the virus particle and aggregation}

Approaching the isoelectric point of a macromolecule (carrying a net negative surface charge when dispersed in a $\mathrm{pH}$-neutral aqueous phase) at decreased $\mathrm{pH}$ values decreases the repulsive forces between single macromolecules. This may support particle aggregation due to hydrogen bonding. Enveloped viruses are known to be sensitive to low $\mathrm{H}_{3} \mathrm{O}^{+}$activities (Gaudin et al., 1995). Also, $\mathrm{pH}$ changes resulting in virus particle aggregation have been correlated previously with decreased baculovirus infectivity (Jorio et al., 2006b).

The literature reports the isoelectric point of various baculoviruses in the range of $\mathrm{pH} 4$ to 6. The isoelectric point of the CMV-Luc baculovirus has been estimated at pH 5.4 (Yang et al., 2009). Based on flow cytometry experiments, Jorio et al. demonstrated aggregation of AcMNPV's budded virus accompanied by an infectivity loss at $\mathrm{pH}$ 5.3. Using theory and dynamic light scattering experiments a minimum $\zeta$-potential of an AcMNPV dispersion has been estimated in the range of $\mathrm{pH}$ 4-6 (at ca. 4.7) (Vicente et al., 2010).

Increased light absorbance commencing between pH 4-6 (Fig. 2, see 3.1) is evidence for aggregation of viral particles, cell debris or proteins in dispersion. Maximum light absorbance 
and infectivity decreased by ca. 3 orders of magnitude at $25^{\circ} \mathrm{C}$ was detected at $\mathrm{pH} 4.1 \pm 0.3$. This may be rationalized with aggregation of viral particles due to a minimized electrostatic surface potential. Similarly, resolved aggregation of viral particles with an irreversible loss in viral infectivity may be hypothesized when further decreasing the $\mathrm{H}_{3} \mathrm{O}^{+}$activity to $\mathrm{pH} 3$. Increased light absorbance and stable infectivity at $\mathrm{pH} 8.0 \pm 0.2$ may be due to aggregation of cell debris and HCP. As a major conclusion, the experimental results presented support the evidence for an isoelectric point of the recombinant of AcMPNV tested near $\mathrm{pH} 4.1 \pm 0.3$.

\subsubsection{Virus particle stability and osmotic pressure}

Low ionic conductivity in virus dispersions resulting in decreased infectivity (see 3.1 ) has been linked previously to an increased osmotic pressure, e.g., for the enveloped Sindbis virus (Waite et al., 1968). To estimate the related change in osmotic pressure the following assumes a dilute and incompressible liquid phase and a negligible total virus plasma volume (vp) compared to the volume of the virus dispersion (vd). Thus, the absolute osmotic pressure $(\pi)$ gradient (Prausnitz et al., 1999) over the viral membrane after the addition of salt reduced by the osmotic pressure gradient before the addition of salt $\left(\delta \pi_{a b s}\right)$ can be written as:

$$
\delta \pi_{\mathrm{abs}}=\left(\left.\pi\right|_{\mathrm{vd}+\text { salt }}-\left.\pi\right|_{\mathrm{vp}}\right)-\left(\left.\pi\right|_{\mathrm{vd}}-\left.\pi\right|_{\mathrm{vp}}\right)=\left|\frac{R T}{v_{d}} \sum_{j=\text { salts added }} i_{j} n_{j}\right|
$$

where $R$ is the gas constant in $\mathrm{J} / \mathrm{K} / \mathrm{mol}, T$ is the liquid temperature in $\mathrm{K}$, and $v_{d}$ in $\mathrm{m}^{3} / \mathrm{kg}$ is the specific volume (approximated with water at ambient conditions) available to $i_{j} n_{j}$ mol osmotic active ions (determined analytically) in osmol $/ \mathrm{kg} \mathrm{H}_{2} \mathrm{O}$.

The infectivity of the virus dispersion increased slightly when $\kappa$ increased from 8.1 to 10 $20 \mathrm{mS} / \mathrm{cm}$ (i.e., addition of $0.05-0.10 \mathrm{~mol} / 1 \mathrm{NaCl}$ increasing presumably the water flux from the virus particle into the surrounding medium). Decreasing $\kappa$ to $5 \mathrm{mS} / \mathrm{cm}\left(\delta \pi_{a b s}=0.49 \pm 0.07 \mathrm{MPa}\right)$ inactivated instantaneously the major fraction of the dispersed virus. This may be contributed to 
a rapidly increased water flux from the surrounding liquid phase into the virus particle. Similarly, Chen et al. reported stable infectivity of a recombinant baculovirus (AcVSVG-CAGFP dispersed in $20 \mathrm{mmol} / \mathrm{l}$ Tris buffer with an addition of PBS) when adding $\mathrm{NaCl}$ in the range of 0.1 to 0.3 mol/1 (i.e., ca. 4.2-6.7 mS/cm). At lower salt concentrations infectivity decreased (Chen et al., 2009). Increasing $\kappa$ to $25 \mathrm{mS} / \mathrm{cm}\left(\delta \pi_{a b s}=1.00 \pm 0.03 \mathrm{MPa}\right)$ inactivated the major fraction of AcMNPV in dispersion after $24 \mathrm{~h}$. The time required for virus inactivation at increased ionic conductivity may point towards a relatively slow water flux from the virus particle into the surrounding medium resulting in temporality stable virus dispersions at increased $\kappa$.

In summary, the recombinant of AcMNPV appears to maintain long-term infectivity when increasing the water flux from the virus particle to the surrounding medium at $\delta \pi_{a b s}<1$. Infectivity is reduced slowly when further increasing this pressure. The virus is inactivated instantaneously when reversing the direction of the osmotic pressure (water flux from the surrounding liquid phase into the virus particle).

\subsection{Virus concentration via IEMC}

Three strong anion exchange membranes were tested for concentration and purification of AcMNPV. Aiming for comparable process conditions, all membranes were tested under equal adsorption, washing, and elution conditions. Concentration results may alter when optimizing these conditions for each membrane material separately. This section discusses recovery and concentration of infectivity (see 3.2, Fig. 4, Fig.5, and Table 1). Purification with respect to HCP and DNA levels is discussed in section 4.3.

\subsubsection{Virus adsorption}

Approaching the break-through (significant infectivity detected in the fraction 3 ) ensures that binding capacities reported here (Table 1) reflect approximately the total capacities of the 
tested materials. The high capacity of the CS membrane for AcMNPV's budded virus is likely due to a relative small bed volume employed causing an early and complete break-through of viral particles (Fig. 4). Lower total binding capacities of the MQ and SQ membranes compared to the CS membrane can thus not be inferred unerringly. For comparison, binding capacities for other viruses to strong anion exchange membranes have been reported previously in a similar range (Han et al., 2005; Kutner et al., 2009; Woo et al., 2011; Wu et al., 2007).

\subsubsection{Virus elution}

Data from at least two experiments (using the MQ or SQ material respectively) support successful maintenance of infectivity when exposing virus dispersions for $<1 \mathrm{~h}$ to an increased ionic conductivity. Furthermore, IEMC using the MQ membrane yielded a virus concentration factor in accord with the volume reduction allowing a theoretical concentration by a factor of three. In the future this may be further increased, e.g., by decreasing the eluate volume or optimizing the trans-membrane flux during the adsorption step.

High virus recovery and efficient concentration distinguish the cellulose- or polyether sulfone-based membranes with quaternary ammonium ligands (SQ or MQ) as applicable materials for mild, scalable, and economically attractive virus concentration, e.g., for the production of biopesticides (see 1.). The SDS-PAGE confirms virus concentration qualitatively using these materials (Fig.5). Given the irreversible binding of AcMPNV particles to the CS membrane at the tested conditions, poly(allylamine)-coated polyethylene membranes may be used as a simple and efficient part of viral de-concentration processes. Alternatively, these membranes may be utilized for the purification of proteins carrying a net positive surface charge. 


\subsection{Virus purification}

Elution experiments were conducted under non-isoelectric conditions ( $\mathrm{pH}$ 6.1) aiming for a maximum viral product yield rather than for maximum product purity. For comparability, all membranes were tested under equal elution conditions. That is purification results may be increased by optimizing elution conditions for each membrane material separately.

All tested membrane materials decreased the HCP concentration significantly, up to below the detection limit using the MQ membrane (see 3.3). The SDS-PAGE confirms qualitatively decreased HCP concentrations for all three membrane materials (Fig.5). With regard to allergenic proteins which may be contained in baculovirus suspensions, such as glycoprotein (Heimpel et al., 1967), this could be advantageous when considering clinical applications of the virus studied here.

Furthermore, about $28.3 \mathrm{wt} \%(\mathrm{MQ}), 54.8 \mathrm{wt} \%$ (SQ) or $59.8 \mathrm{wt} \%(\mathrm{CS})$ of HCP relative to the total HCP present in the virus dispersion processed bound irreversibly to the membrane. This assumes that irreversible binding of HCP can be estimated by the difference between the HCP contained in the total volume of virus dispersion filtered and the HCP recovered in all samples collected. This together with maximum binding capacities of up to $30 \mathrm{mg}$ bovine serum albumin per $\mathrm{ml}$ (manufacturer certificate) point out the possibility to recycle the tested membranes without the need for additional chemicals introduced into the process. Based on the experimental results reported here the MQ material appears most promising for reduction of $\mathrm{HCP}$.

IEMC decreased the concentration of free DNA by 77.1-99.1 wt\% (Fig. 6). During the course of the filtration experiments, a small amount of DNA adsorbed to the membranes, relative to the adsorbed protein fractions (Fig. 4 and 6). Washing or elution at $0.5 \mathrm{~mol} / \mathrm{l} \mathrm{NaCl}$ eluted quickly a major fraction of the adsorbed DNA from the MQ and SQ materials. The remainder, $33.3 \mathrm{wt} \%$ (MQ), $30.5 \mathrm{wt} \%(\mathrm{SQ})$, or $31.5 \mathrm{wt} \%$ respectively, may be assumed to have bound 
irreversibly to the membranes. This suggests relative weak interactions between the DNA and the membrane materials, compared to the interactions of suspended protein. The MQ and SQ materials in particular can be regenerated with increased salt concentrations.

The potential risk arising from DNA impurities in virus samples for clinical applications has to be weighed on a case-by-case basis (FDA, 1997; ICH, 1996; WHO, 1998). In general, the potential risk associated with baculoviral DNA or DNA arising from an insect cell line has been deemed previously as low relative to potentially allergenic protein, such as glycoprotein (see above, this section) (Heimpel et al., 1967). However, assuming a single clinical dose containing a total of $10^{6}$ active vectors yields theoretically about $93 \mathrm{pg} / \mathrm{dose}$, i.e., when using the MQ material for virus concentration and purification (maximum DNA level in the eluate relative to the concentrated infectivity, based on the DNA reduction and virus concentration factors estimated at 3.3, and 3.2, or 4.2.2 respectively). This would be sufficiently low to confirm with FDA guidelines suggesting an application-specific maximum of ca. 100 pg/dose (FDA, 1997; ICH, 1996; WHO, 1998). If lower active vector levels would suffice the specific application than

the SQ material may decrease free DNA to the desired level as well, e.g., 32 pg DNA per $10^{5}$ pfu.

\section{Conclusions}

Ion exchange membrane chromatography may be used for virus downstream processing at large scale yielding high concentrations of recovered infectivity or high product purity dependent on the choice of process parameters. To guide this choice for the separation of a recombinant of AcMNPV virus stability dependent on $\mathrm{pH}$ and ionic conductivity was assessed (see 4.1). Results support the evidence for an isoelectric point of the budded virus (see 4.1.1) and 
provide a semi-quantitative kinetic study of the relation between ionic conductivity, osmotic pressure, and viral infectivity (see 4.1.2).

Concentration and purification of the virus in a single process step using strong anion exchange membranes were demonstrated under comparable process conditions. Optimization of these conditions for a given membrane material may advance the process performance. A maximum virus concentration factor was obtained with a polyether sulfone-based membrane carrying quaternary ammonium functional groups (see 4.2). Impurities arising from host cell protein could be decreased below the detection limit using this material. Also, filtration with membranes carrying quaternary ammonium functional groups could diminish the level of suspended DNA to below 100 pg per $10^{5}$ to $10^{6}$ pfu (see 4.3 ).

Aiming for maximum product purity, future work may explore ion exchange membrane chromatography employing rapid and selective elution of the virus near its isoelectric point. This

may require means to prevent or reverse aggregation. Alternatively, an increased recovery of infectivity when increasing salt concentrations in the eluate and short-term maintenance of infectivity at these conditions outlines the possibility of to increase separation efficiencies at increased salt concentrations.

\section{Acknowledgements}

We would like to thank the Hessen State Ministry of Higher Education, Research and the Arts for the financial support within the Hessen initiative for scientific and economic excellence (LOEWE-Program). The authors would like to thank Prof. Lorena Passarelli for provision of vHSGFP. 


\section{References}

Aboud, M., Wolfson, M., Hassan, Y., Huleihel, M., 1982. Rapid purification of extracellular and intracellular Moloney murine leukemia virus. Arch Virol 71, 185-95.

Aranha, H., 2001. Viral Clearance Strategies for Biopharmaceutical Safety: Part 2, Filtration for Viral Clearance. BioPharm International, 32-43.

Aucoin, M.G., Mena, J.A., Kamen, A.A., 2010. Bioprocessing of baculovirus vectors: a review. Curr Gene Ther 10, 174-86.

Barsoum, J., 1999. Concentration of recombinant baculovirus by cation-exchange chromatography. Biotechniques 26, 834-6, 838, 840.

Betting, D.J., Mu, X.Y., Kafi, K., McDonnel, D., Rosas, F., Gold, D.P., Timmerman, J.M., 2009. Enhanced immune stimulation by a therapeutic lymphoma tumor antigen vaccine produced in insect cells involves mannose receptor targeting to antigen presenting cells. Vaccine 27, 250-259.

Chen, G.-Y., Chen, C.-Y., Chang, M.D.-T., Matsuura, Y., Hu, Y.-C., 2009. Concanavalin a affinity chromatography for efficient baculovirus purification. Biotechnol. Progress 25, $1669-1677$.

FDA, Center for Biologics Evaluation and Reseach.; 1997. Reviewer Guidance: Points to Consider in the Manufacture and Testing of Monoclonal Antibody Products for Human Use; Docket No. 94D-0259

Gaudin, Y., Ruigrok, R.W.H., Brunner, J., 1995. Low-pH induced conformational changes in viral fusion proteins: implications for the fusion mechanism. J. Gen. Virol. 76, 15411556.

Ghosh, R., 2002. Protein separation using membrane chromatography: opportunities and challenges. J Chromatogr. A 952, 13-27.

Goley, E.D., Ohkawa, T., Mancuso, J., Woodruff, J.B., D'Alessio, J.A., Cande, W.Z., Volkman, L.E., Welch, M.D., 2006. Dynamic Nuclear Actin Assembly by Arp2/3 Complex and a Baculovirus WASP-Like Protein. Science 314, 464-467.

Han, B., Specht, R., Wickramasinghe, S.R., d Carlson, J.O., 2005. Binding Aedes aegypti densonucleosis virus to ion exchange membranes. J. Chromatogr. A 1092, 114-124.

Heimpel, A.M., Buchanan, L.K., 1967. Human feeding tests using a nuclear-polyhedrosis virus of Heliothis zea. J. Invert. Pathol. 9, 55-57.

ICH. International Conference of Harmonisation 1996. Topic Q2(R1)Validation of Analytical Procedures: Text and Methodology, http://www.ich.org. 
Ihalainen, T.O., Laakkonen, J.P., Paloheimo, O., Yla-Herttuala, S., Airenne, K.J., Vihinen-Ranta, M., 2009. Morphological characterization of baculovirus Autographa californica multiple nucleopolyhedrovirus. Virus Res 148, 71-4.

Jarvis, D.L., Garcia, A., Jr., 1994. Long-term stability of baculoviruses stored under various conditions. Biotechniques 16, 508-13.

Jorio, H., Tran, R., Kamen, A., 2006a. Stability of serum-free and purified baculovirus stocks under various storage conditions. Biotechnol Prog 22, 319-25.

Jorio, H., Tran, R., Meghrous, J., Bourget, L., Kamen, A., 2006b. Analysis of baculovirus aggregates using flow cytometry. J. Virol. Methods 134, 8-14.

Justice, C., Brix, A., Freimark, D., Kraume, M., Pfromm, P., Eichenmueller, B., Czermak, P., 2011. Process control in cell culture technology using dielectric spectroscopy. Biotechnol. Adv. 29, 391-401.

Klein, E., 2000. Affinity membranes: a 10-year review. J. Membr. Sci. 179, 1-27.

Kutner, R., Puthli, S., Marino, M., Reiser, J., 2009. Simplified production and concentration of HIV-1-based lentiviral vectors using HYPERFlask vessels and anion exchange membrane chromatography. BMC Biotechnology 9, 10.

Liang, C.Y., Wang, H.Z., Li, T.X., Hu, Z.H., Chen, X.W., 2003. High efficiency gene transfer into mammalian kidney cells using baculovirus vectors. Arch. Virol. 149, 51-60.

Long, G., Pan, X., Kormelink, R., Vlak, J.M., 2006. Functional Entry of Baculovirus into Insect and Mammalian Cells Is Dependent on Clathrin-Mediated Endocytosis. J. Virol. 80, 8830-8833.

Michalsky, R., Passarelli, A.L., Pfromm, P.H., Czermak, P., 2009. Purification of the baculovirus Autographa californica $M$ nucleopolyhedrovirus by tangential flow ultrafiltration. Desalination 245, 694-700.

Michalsky, R., Pfromm, P.H., Czermak, P., Sorensen, C.M., Passarelli, A.L., 2008. Effects of temperature and shear force on infectivity of the baculovirus Autographa californica $\mathrm{M}$ nucleopolyhedrovirus. J Virol Methods 153, 90-6.

Mishra, S., 1998. Baculovirus as biopesticides. Curr. sci. 75, 1015-1022.

Moscardi, F., 1999. Assessment of the application of baculoviruses for control of Lepidoptera. Annu Rev Entomol 44, 257-89.

O’Reilly, D.R., Miller, L.K., Luckow, V.A., 1994. Baculovirus Expression Vectors: A Laboratory Manual. Oxford University Press, New York.

Oliveira, J.V.d.C., Wolff, J.L.C., Garcia-Maruniak, A., Ribeiro, B.M., de Castro, M.E.B., de Souza, M.L., Moscardi, F., Maruniak, J.E., Zanotto, P.M.d.A., 2006. Genome of the most widely used viral biopesticide: Anticarsia gemmatalis multiple nucleopolyhedrovirus. J. Gen. Virol. 87, 3233-3250. 
Prausnitz, J.M., Lichtenthaler, R.N., Gomes de Azevedo, E., 1999. Molecular Thermodynamics of Fluid-Phase Equilibria. Prentice Hall PTR, Upper Saddle River, NJ, USA.

Rohrmann, G.F., 1992. Baculovirus structural proteins. J. Gen. Virol. 73, 749-761.

Roldão, A., Oliveira, R., Carrondo, M.J.T., Alves, P.M., 2009. Error assessment in recombinant baculovirus titration: Evaluation of different methods. J. Virol. Methods 159, 69-80.

Transfiguracion, J., Mena, J.A., Aucoin, M.G., Kamen, A.A., 2011. Development and validation of a HPLC method for the quantification of baculovirus particles. J Chromatogr B Analyt Technol Biomed Life Sci 879, 61-8.

Vicente, T., Peixoto, C., Alves, P.M., Carrondo, M.J.T., 2010. Modeling electrostatic interactions of baculovirus vectors for ion-exchange process development. J. Chromatogr. A $1217,3754-3764$.

Vicente, T., Peixoto, C., Carrondo, M.J., Alves, P.M., 2009. Purification of recombinant baculoviruses for gene therapy using membrane processes. Gene Ther 16, 766-75.

Waite, M.R., Pfefferkorn, E.R., 1968. Effect of altered osmotic pressure on the growth of Sindbis virus. J Virol 2, 759-60.

WHO, 1998. Forty-seventh Report Technical Report Series, No 878. WHO Expert Committee on Biological Standardization, ISBN 9241208783.

Woo, M., Khan, N.Z., Royce, J., Mehta, U., Gagnon, B., Ramaswamy, S., Soice, N., Morelli, M., Cheng, K.-S., 2011. A novel primary amine-based anion exchange membrane adsorber. J. Chromatogr. A 1218, 5386-5392.

Wu, C., Soh, K.Y., Wang, S., 2007. Ion-exchange membrane chromatography method for rapid and efficient purification of recombinant baculovirus and baculovirus gp64 protein. Hum Gene Ther 18, 665-72.

Yang, H., Viera, C., Fischer, J., Etzel, M.R., 2002. Purification of a Large Protein Using IonExchange Membranes. Ind. Eng. Chem. Res. 41, 1597-1602.

Yang, Y., Lo, S.-L., Yang, J., Yang, J., Goh, S.S.L., Wu, C., Feng, S.-S., Wang, S., 2009. Polyethylenimine coating to produce serum-resistant baculoviral vectors for in vivo gene delivery. Biomaterials 30, 5767-5774. 


\section{Tables}

\begin{tabular}{|c|c|c|}
\hline \multirow{2}{*}{$\begin{array}{c}\text { IEMC } \\
\text { Material }\end{array}$} & \multicolumn{2}{|c|}{ adsorbed virus $^{a}$} \\
\hline & (pfu / $\mathrm{m}^{3}$ bed volume) & (pfu / $\mathrm{m}^{2}$ inflow area) \\
\hline$M Q$ & $(2.01 \pm 1.01) \times 10^{15}$ & $(1.98 \pm 1.00) \times 10^{12}$ \\
\hline$S Q$ & $(2.03 \pm 1.00) \times 10^{15}$ & $(1.70 \pm 0.84) \times 10^{12}$ \\
\hline \multirow[t]{3}{*}{ CS } & $(1.14 \pm 0.64) \times 10^{16}$ & $(9.12 \pm 5.12) \times 10^{12}$ \\
\hline & \multicolumn{2}{|c|}{ desorbed virus $^{a}$} \\
\hline & (pfu / $\mathrm{m}^{3}$ bed volume) & (pfu / $\mathrm{m}^{2}$ inflow area) \\
\hline$M Q$ & $(2.28 \pm 0.29) \times 10^{15}$ & $(2.25 \pm 0.29) \times 10^{12}$ \\
\hline SQ & $(1.81 \pm 0.14) \times 10^{15}$ & $(1.52 \pm 0.12) \times 10^{12}$ \\
\hline CS & $(2.31 \pm 0.05) \times 10^{11}$ & $(1.85 \pm 0.04) \times 10^{8}$ \\
\hline
\end{tabular}

Table 1: Apparent binding capacities of a recombinant baculovirus of AcMNPV purified using three different strong anion exchange membranes (see 2.6); a, data are given as infectivity relative to the chromatographic bed volume or relative to the membrane area facing the incident fluid flow (area intersecting the flow per layer times number of layers utilized) respectively.

\section{Figures}

Figure 1: Schematic setup of virus production and one-step virus concentration and purification.

Figure 2: Infectivity of virus dispersions and absorbance at $595 \mathrm{~nm}$ vs. pH. A line was added to guide the eye. Error bars are one standard deviation.

Figure 3: Infectivity (instantaneously or after $24 \mathrm{~h}$ storage) vs. ionic conductivity in the liquid phase. Lines were added to guide the eye. Error bars reflect the average uncertainty reported previously for the assay quantifying viral infectivity (see 2.2). 
Figure 4: Separation of AcMNPV using three different anion exchange membranes. All fractions are $1 \mathrm{ml}$. Eluate I contains $0.15 \mathrm{~mol} / 1 \mathrm{NaCl}$, eluate II contains $0.5 \mathrm{~mol} / \mathrm{l} \mathrm{NaCl}$. The acronyms of the tested membrane materials are given at 2.6. Error bars are one standard deviation for samples analyzed in triplicate.

Figure 5: SDS-PAGE analysis for a relative comparison of protein present in AcMNPV dispersions purified by three different adoptive membranes (MQ, SQ, or CS): The initial and final fraction of the washing step (fraction 4 and 9) on the left and samples from the first (150 $\mathrm{mM} / \mathrm{L} \mathrm{NaCl}$ ) and second (500 mM/L NaCl) elution step (fraction 11 and 14) on the right. Bands correlating presumably with the virus-specific GP64 are marked (arrow).

Figure 6: Concentration of total suspended DNA during the course of three filtration experiments (acronyms of the tested membrane materials are given at 2.6). The DNA level of harvested virus dispersion was $674 \pm 35 \mathrm{ng} / \mathrm{ml}$. The Relative standard deviation of five-fold repeated measurements is $5.22 \%(95.4 \%$ confidence interval $)$. 